\title{
EFFECT OF OCCUPATIONAL HEALTH AND SAFETY ON EMPLOYEE WORK PRODUCTIVITY AT ENGINEERING SECTION OF PT. PLN (PERSERO) MASOHI BRANCH IN CENTRAL MALUKU REGENCY, INDONESIA
}

\author{
Paais Maartje \\ Department of Management, Faculty of Economics and Management, \\ University of Christian Indonesia, Ambon, Indonesia \\ E-mail: maartjepaais19@gmail.com
}

\begin{abstract}
Occupational Safety and Health (K3) should be the main priority of the company, but unfortunately not all companies understand the significance of K3 and know how to implement it well in the corporate environment. This research aims to determine the influence of occupational safety and Health to the productivity of employees ' work section of PT. PLN (Persero) Branch of Masohi regency of central Maluku. The sampling in this study was used as much as 50 respondents; the technique of data collection is with questionnaires, the research variables are health $(X 1)$, Safety $(X 2)$, Productivity $(Y)$. Data was tested for validation by using the Pearson Product Moment correlation, and for testing its reliability level using Cronbach Alpha and later data processed with multiple linear regression analyses. The results of this study show that there is a significant influence of each of these variables on work productivity.
\end{abstract}

\section{KEY WORDS}

Safety, health, productivity, public service.

In this globalization era, competition in the increasingly competitive energy industry requires companies to optimize all available resources in producing high quality products in order to survive in the competition (Lacal-Arántegui; 2019; O'brien, 2019; Malik, 2019). Electricity has become a major requirement for modern society. Electricity has changed human civilization to become easier, faster, efficient, effective, and productive since it was first discovered (Palmer-Wilson et al., 2019; Barnes, 2019). Electricity has experienced significant progress, this can be seen by the efforts that have been and are being carried out in its development.Specifically, the implementation of the Occupational Safety and Health program is necessary and very important because it helps the realization of good employee maintenance, so that they realize the importance of implementing an occupational safety and health program for themselves and the company.

The program is ultimately expected to improve company performance and employee work productivity as has been indirectly confirmed in the legislation previously described. According to Milyandra (2009) Poor employee safety and health at work will clearly hamper the production process carried out by each employee in each department that is accounted for by the employee (Wilson et al., 2004; Benach et al., 2014; Skład, 2019; Zanchi et al., 2019). If the production process is hampered, it will have implications for decreasing employee output (productivity). As revealed by Lestari and Trisulianti (2009) in their research that occupational health and safety has a positive relationship on employee productivity. Then reinforced by the theory which was stated by Husni stating that work safety is related to work accidents that can disrupt the process that has been arranged in an activity.

In general, work accidents are caused by two factors, namely humans and the environment. Human factors namely unsafe actions from humans such as deliberately violating the required safety regulations and lack of skilled workers themselves. While environmental factors, namely the insecurity of the work environment involving, among others, equipment or machinery, but the frequency of work accidents is mostly due to human factors, because humans play the most role in using equipment in the company. 
The maximum work productivity of employees on the other hand PT PLN (Persero) Branch of Masohi, Central Maluku Regency has a form of occupational health and safety program, which consists of employee health insurance, work environment, and infrastructure, where the three forms of the K3 program are theoretically have positive relationship on the employee work productivity which will lead on the increase in profitability. As stated by Ravianto in Daud's quote (2012) that social security, a good work environment, and production facilities are factors that affect employee work productivity. So, with the implementation of the K-3 program, employees will feel safe, protected and guaranteed safety, so that it is expected to achieve efficiency either in terms of cost, time and energy and can increase work productivity for employees. $\mathrm{n}$ line with the problems that have been formulated above, then the objectives to be achieved in this study are: 1). To find out whether occupational safety and health variables affect simultaneously and partially on the work productivity of the employees of the technical department of PT PLN (Persero) Branch of Masohi, Central Maluku Regency. 2). To find out whether the work safety variable has a dominant effect on the Employee Productivity of the Technical Section of PT PLN (Persero), Masohi Branch, Central Maluku Regency

\section{METHODS OF RESEARCH}

The populations in this study were all employees of PT. PLN (Persero) Branch of Masohi, Central Maluku Regency totaling 50 people. While the samples of this study were all employees of the Engineering Section of PT. PLN (Persero) Masohi Branch of Central Maluku Regency, using the census method, where all members of the population are taken as samples.

As for the operational definitions of each variable in this study are as follows:

Occupational Safety (X1). An indicator used to measure occupational safety: Workplace Situation; Air Settings; Lighting settings; Use of Work Equipment; Physical and mental condition of employees.

Occupational Health (X2). Indicators used to measure occupational health: State and Condition of Employee; Work Environment; Employee Protection.

Productivity $(Y)$. Indicator used to measure productivity: Quality of work; Work quantity; Timeliness; Work spirit; Work discipline.

The analysis technique used in this study is quantitative, namely testing and analyzing data by calculating numbers and then drawing conclusions and testing with multiple linear regressions.

\section{RESULTS AND DISCUSSION}

Conducted with the product moment correlation approach between each item that measures a variable with a total score of the variable. The criterion used is if the correlation coefficient ( $r$ calculate) is positive and greater than $r$ table, it means that the item is declared valid.

From table 1, each statement item used in this study has a correlation value that is greater than $r$ table (0.312) so that the statement item submitted is valid and worth to be analyzed.

Instrument reliability testing uses Cronbach's Alpha coefficient with the provisions that the reliability coefficient of each variable must be greater than 0.60 , which means reliable.

The reliability test results in Table 2 show that the Cronbach's Alpha reliability coefficient value of each variable is greater than 0,60 which means reliable. Cronbach's Alpha coefficient values obtained ranged from 0,783 to 0,914 . Thus all the questions in the research instrument are feasible as instruments to measure the variables of Occupational Safety, Health and Productivity, because they meet the recommended validity and reliability requirements.

Multicollinearity Test aims to test whether the regression model found a correlation between independent variables. A good regression model should not occur correlation 
between independent variables. Regression model is said to be free of multicollinearity if VIF $<10$. VIF test results can be seen in table 3 .

Table 1 - Validity Testing

\begin{tabular}{|c|c|c|c|c|}
\hline Variable & Question Item & Product Moment & $\mathrm{R}_{\text {table }}$ & Information \\
\hline $\begin{array}{c}\mathrm{X} 1 \\
\text { Occupational Safety }\end{array}$ & $\begin{array}{l}\mathrm{X} 1.1 \\
\mathrm{X} 1.2 \\
\mathrm{X} 1.3 \\
\mathrm{X} 1.4 \\
\mathrm{X} 1.5 \\
\mathrm{X} 1.6 \\
\mathrm{X} 1.7 \\
\mathrm{X} 1.8 \\
\mathrm{X} 1.9\end{array}$ & $\begin{array}{l}0.566 \\
0.638 \\
0.513 \\
0.572 \\
0.501 \\
0.723 \\
0.763 \\
0.472 \\
0.356\end{array}$ & \multirow{3}{*}{0.279} & \multirow{3}{*}{ Valid } \\
\hline $\begin{array}{c}\text { X2 } \\
\text { Occupational Health }\end{array}$ & $\begin{array}{l}\text { X2.1 } \\
\text { X2.2 } \\
\text { X2.3 } \\
\text { X2.4 } \\
\text { X2.5 } \\
\text { X2.6 } \\
\text { X2.7 } \\
\text { X2.8 }\end{array}$ & $\begin{array}{l}0.830 \\
0.852 \\
0.642 \\
0.649 \\
0.801 \\
0.826 \\
0.881 \\
0.862\end{array}$ & & \\
\hline $\begin{array}{c}\mathrm{Y} \\
\text { Productivity }\end{array}$ & $\begin{array}{l}\mathrm{Y} 1.1 \\
\text { Y1.2 } \\
\text { Y1.3 } \\
\text { Y1.4 } \\
\text { Y1.5 } \\
\text { Y1.6 } \\
\text { Y1.7 } \\
\text { Y1.8 } \\
\text { Y1.9 } \\
\text { Y1.10 }\end{array}$ & $\begin{array}{l}0.781 \\
0.809 \\
0.522 \\
0.508 \\
0.725 \\
0.783 \\
0.656 \\
0.697 \\
0.523 \\
0.311\end{array}$ & & \\
\hline
\end{tabular}

Source: Data Processed, 2019.

Table 2 - Reliability Testing

\begin{tabular}{|c|c|c|c|}
\hline Variable & Alpha Cronbach & Criteria & Information \\
\hline $\mathrm{X} 1$ & 0.783 & \multirow{3}{*}{$\geq 0,60$} & Reliable \\
\hline $\mathrm{X} 2$ & 0.789 & & Reliable \\
\hline $\mathrm{Y}$ & 0.914 & & Reliable \\
\hline
\end{tabular}

Source: Data Processed, 2019.

Table 3 - Multicollinear Test

\begin{tabular}{|c|l|c|c|}
\hline \multicolumn{2}{|c|}{ Model } & \multicolumn{2}{c|}{ Collinearity Statistics } \\
\cline { 3 - 4 } \multicolumn{2}{|c|}{} & \multicolumn{2}{c|}{ Tolerance } \\
\hline \multirow{3}{*}{1} & (Constant) & .389 & 2.569 \\
\cline { 2 - 4 } & Occupational Safety & .389 & 2.569 \\
\cline { 2 - 4 } & Occupational Health & & \\
\hline
\end{tabular}

Dependent Variable: Productivity.

Source: Data Processed, 2019.

The test results in table 3 above show that all variables used in the regression model show that the VIF value is $1-10$. So that it can be concluded that the variables in this study did not indicate the presence of multicollinearity symptoms.

In principle the normality can be detected by looking at the spread of data on diagonal axis of the graph or by looking at the histogram of its residuals. Basic decision making:

- If the data spreads around the diagonal line and follows the direction of the diagonal line or the histogram graph shows a normal distribution, then the regression model meets the normality assumption;

- If the data is spread far from the diagonal or does not follow the direction of the diagonal line or the histogram graph does not show a normal distribution, then the regression model does not meet the assumption of normality Ghozali, (2013:156). 


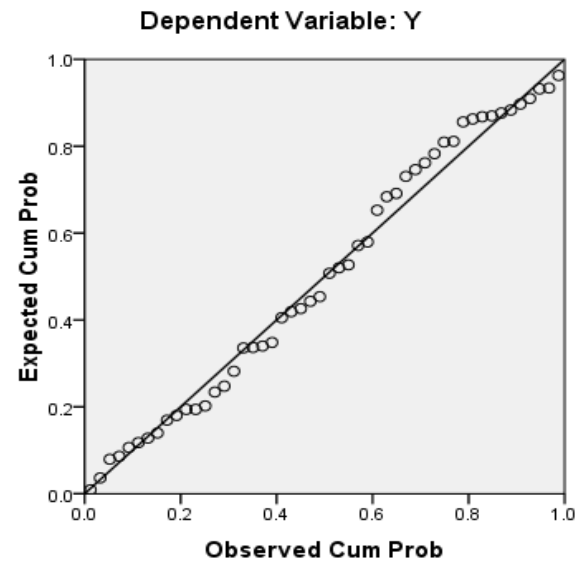

Figure 1 - Data Normality Graph

Based on graph of Normal P-PLOT of Regression Standardized residual, it shows that the residual points of the regression model are normally distributed because these points spread around the diagonal line, thus the normality requirements as statistical tests using regression can be fulfilled.

Scatterplot

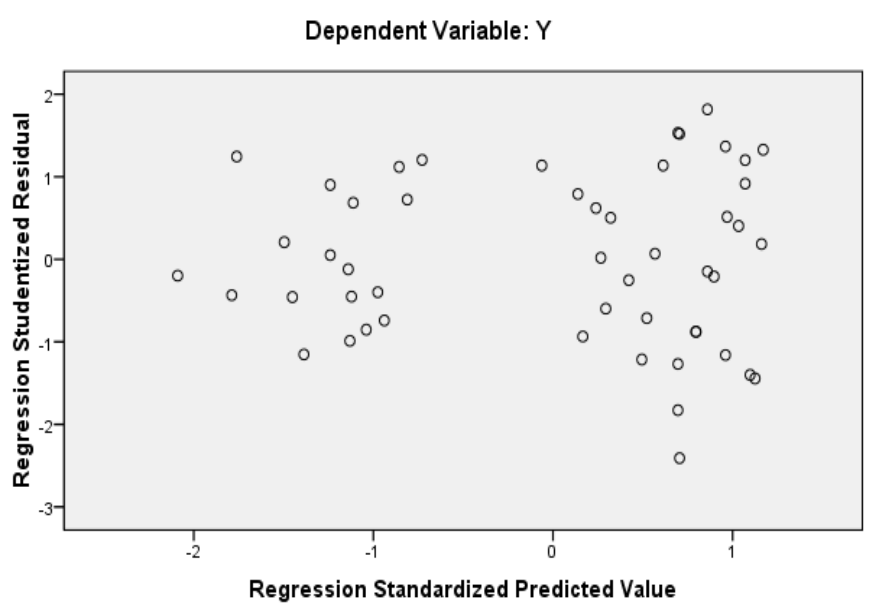

Figure 2 - Heteroscedasticity Test Results

Heteroscedasticity test results show, that the points that spread randomly, do not form a certain pattern that is clear, and spread both above and below the number 0 (Zero) on the $Y$ axis this means that there is no deviation from the classical assumption of Heteroscedasticity in the regression model that was made.

The autocorrelation test uses the Durbin-Watson (DW) test. Santoso (2011) there are 3 criteria for autocorrelation:

- DW values below -2 mean there is a positive autocorrelation indicated;

- DW values between -2 to 2 mean that there is no autocorrelation;

- DW value above 2 means that a negative autocorrelation is indicated.

Multiple linear regression analysis is used to test hypotheses about the effect of partially and simultaneously the independent variables on the dependent variable. 
From the previous analysis it was proven that this research was considered good. The results of the SPSS are used as an analysis tool, and then the results of multiple regressions are as follows in Table 5.

Tabel 4 - Autocorrelation Test

Model Summary ${ }^{\mathrm{b}}$

\begin{tabular}{|l|l|l|l|l|l|}
\hline Model & R & R Square & Adjusted R Square & Std. Error of the Estimate & Durbin-Watson \\
\hline 1 & $.862^{\mathrm{a}}$ & .743 & .732 & 3.63601 & .969 \\
\hline
\end{tabular}

a. Predictors: (Constant), X2, X1.

b. Dependent Variable: $Y$

Table 5 - Multiple Linear Regression Test

Coefficients $^{\mathrm{a}}$

\begin{tabular}{|c|c|c|c|c|c|}
\hline \multirow[b]{2}{*}{ Model } & \multicolumn{2}{|c|}{ Unstandardized Coefficients } & \multirow{2}{*}{\begin{tabular}{|l} 
Standardized Coefficients \\
Beta
\end{tabular}} & \multirow[b]{2}{*}{$\mathrm{T}$} & \multirow[b]{2}{*}{ Sig. } \\
\hline & $\mathrm{B}$ & Std. Error & & & \\
\hline 1 (Constant) & 6.952 & 2.859 & & 2.432 & .019 \\
\hline $\mathrm{X} 1$ & .607 & .141 & .510 & 4.297 & .000 \\
\hline X2 & .387 & .114 & .403 & 3.396 & .001 \\
\hline
\end{tabular}

a. Dependent Variable: $Y$

Source: Data Processed, 2019.

The multiple linear regression equation can be formulated as follows:

$$
\mathrm{Y}=6.952+0.607 \mathrm{X} 1+0,387 \mathrm{X} 2+\mathrm{e}
$$

Where: $\mathrm{Y}=$ Productivity; $\mathrm{X} 1=$ Occupational Safety; $\mathrm{X} 2=$ Occupational Health; $\mathrm{e}=$ Error.

The analysis results can be interpreted as follows:

- A constant value of 6.952 then this can be interpreted that if the safety variable (X1), the health variable (X2) is constant or unchanged, then the employee productivity amounted to 6.952;

- Regression coefficient $X 1$ of 0,607 , then this can be interpreted that the occupational safety variable (X1) affects employee work productivity equal to 0,607 ;

- Regression coefficient $\mathrm{X} 2$ of 0,387 then this can be interpreted that the variable of occupational health (X1) affects the work productivity of employees amounted to 0,387 ;

- Determination Test is used to find out how much the contribution of occupational health and safety variables on the employees productivity of the Technical Section at PT. PLN (Persero) Masohi Branch, Central Maluku Regency. The determination coefficient value is determined by looking at the value of $R$ Square as can be seen in table 6.

Table 6 - Determination Test

Model Summary

\begin{tabular}{|l|l|l|l|l|}
\hline Model & R & R Square & Adjusted R Square & Std. Error of the Estimate \\
\hline 1 & $.862^{\mathrm{a}}$ & .743 & .732 & 3.63601 \\
\hline
\end{tabular}

a. Predictors: (Constant), X2, X1

b. Dependent Variable: $Y$

The analysis results of the factors that affect employee productivity of the Technical Section at PT. PLN (Persero) Masohi Branch of Central Maluku Regency shows that the value of determination (R2) coefficient is 0,743 . This means that the independent variable has a very large contribution to the dependent variable so that it can be said it is very positively related. 
The $\mathrm{F}$ test is a simultaneous test to find out whether occupational health and safety variables and productivity together have a significant influence on the employees performance of the Technical Division of PT. PLN (Persero) Masohi Branch, Central Maluku RegencyFrom the analysis results obtained the output in the following table:

Table 7 - Simultaneous Test (F Test)

ANOVA $^{\mathrm{D}}$

\begin{tabular}{|c|c|c|c|c|c|}
\hline Model & Sum of Squares & df & Mean Square & $F$ & Sig. \\
\hline $\begin{array}{ll}1 & \text { Regression }\end{array}$ & 1793.515 & 2 & 896.757 & 67.831 & $.000^{\mathrm{a}}$ \\
\hline Residual & 621.365 & 47 & 13.221 & & \\
\hline Total & 2414.880 & 49 & & & \\
\hline
\end{tabular}

a. Predictors: (Constant), $\mathrm{X} 2, \mathrm{X} 1$

b. Dependent Variable: $Y$

The results of the $\mathrm{F}$ test statistic calculations in table 7 above show the value of $\mathrm{F}$ calculate is 67.831 After that compared with the $F$ table value of 3,11 with a significant $5 \%$. So it can be concluded that $F$ calculate $>F$ table $(67.831>3,11)$ with a significant 0,000 $<0,05$, This means that the independent variables $(X 1)$ and $(X 2)$ together have a significant positive effect on the employees work productivity of the Technical Section at PT. PLN (Persero) Masohi Branch, Central Maluku Regency.

$T$ test was conducted to determine the effect of each or partially the independent variables on the dependent variable. $T$ test results can be seen below as follows:

Table 8 - Partial Test (T Test)

Coefficients $^{a}$

\begin{tabular}{|l|l|l|l|l|l|}
\hline \multirow{2}{*}{ Model } & \multicolumn{2}{|l|}{ Unstandardized Coefficients } & Standardized Coefficients & & \\
\cline { 2 - 5 } & B & Std. Error & Beta & T & Sig. \\
\hline 1 (Constant) & 6.952 & 2.859 & & 2.432 & .019 \\
X1 & .607 & .141 & .510 & 4.297 & .000 \\
X2 & .387 & .114 & .403 & 3.396 & .001 \\
\hline
\end{tabular}

a. Dependent Variable: $Y$

T test results for the influence of occupational safety X1 on employee work productivity, resulting in a value of $\mathrm{t}$-calculate 4.297 is greater than the value of t table 1.671 with a significance value of 0,000 or smaller than the level of significant (a) 0,05 . From the results of this $t$ test it can be concluded that the occupational safety has a significant effect on employee work productivity.

$T$ test results for the effect of occupational health $\mathrm{X} 2$ on employee work productivity, resulting in a value of $t$-calculate 3.396 greater than the value of $t$ table 1,671 with $a$ significant value of 0,001 or smaller than the level of significant $(\alpha) 0,05$. From the results of this $t$ test it can be concluded that occupational health has a significant effect on employee work productivity.

To find out which variable has the most dominant influence, it can be seen from the magnitude of $t$ calculate. So that it can be seen that the independent variable $X 1$ (occupational / work safety) is the independent variable that has a dominant influence compared to the other independent variables with the highest regression coefficient value namely 0.607 and also has the largest $t$ value namely 4.297 .

\section{DISCUSSION OF RESULTS}

The Effect of Occupational Safety on Employee Work Productivity of the Technical Section at PT. PLN (Persero) Masohi Branch, Central Maluku Regency. Based on the partial results obtained that occupational / work safety (X1) has a positive and significant effect on 
work productivity $(\mathrm{Y})$. This indicates that occupational / work safety is highly prioritized in the process of ongoing activities in PT. PLN (Persero) Masohi Branch, Central Maluku Regency.

This is in line with research conducted by Nia Malinasari entitled "The Effect of Occupational Health and Safety and Social Security Programs on Employee Work Productivity at PT. PJB UP Karangkates Malang Regency" where the results of their research conclude that occupational health and safety (K3) has a positive and tangible relationship on the employee work productivity. Occupational safety is closely related to the increase in productivity. Productivity is the ratio between work output (output) and effort used (input). Occupational can help increase production and productivity on the basis of:

- With a high level of occupational / work safety, accidents that cause illness, disability and death can be reduced to a minimum, so that unnecessary funding can be avoided;

- The high level of safety in line with the maintenance and use of work equipment and machinery for productive and efficient work;

- In many cases, a high level of safety creates conditions that support comfort and excitement of work, so that human factors can be harmonized with the level of efficiency for the continuity of the production process;

- Safety practices are inseparable from skills, both are parallel and are essential elements for the continuity of the production process;

- Occupational / Work safety is carried out as well as possible with the participation of leaders and employees will bring a climate of security/ safety and peace of work, so that it is very helpful for employee and leader relations which is a strong foundation for the creation of a smooth production.

Each manager must realize that to achieve the company's goals are very dependent on work, especially the morale / spirit or enthusiasm of the work of his/her subordinates. Work productivity is a group giving opportunities to people who work to take the maximum part in the company concerned Burton (2008:78).

The Influence of Occupational Health on the Employee Work Productivity of the Technical Section of PT. PLN (Persero) Masohi Branch, Central Maluku Regency. Based on the results obtained that occupational health $(X 2)$ has a positive and significant effect on work productivity $(\mathrm{Y})$. This indicates that occupational health is very much needed and supports the process of ongoing activities in PT. PLN (Persero) Masohi Branch, Central Maluku Regency.

This is in line with research conducted by Lestari and Erlin Trisulianti entitled "Occupational Health and Safety (K3) on Employee Work Productivity in the processing Section of PTPN VIII Gunung Mas Bogor" where the results of their research conclude that occupational health and safety (K3) has a positive and tangible relationship on the employee productivity.

According to Basir Barthos (1993: 150) Occupational diseases if not handled seriously and integrated, can backfire for workers and companies where they work. For workers, occupational diseases can reduce work productivity and reducing the income earned. As for the company, the number of production decreases and gives an unfavorable image of the quality and capacity of the company.

Workers are not robots. For this reason, purely economic considerations may not be good, so it is necessary to "humanize work" or create a more humane working atmosphere. Workers whose welfare is poor, not only causes discouragement but their productivity will decrease. Furthermore they are not interested, apathetic, in doing work and their loyalty to the company will also be reduced.

The influence of occupational safety and health provided has a positive relationship on the employee work productivity of the Technical Section of PT. PLN (Persero) Masohi Branch, Central Maluku Regency. Based on simultaneous results, it was found that occupational safety (X1) and occupational health (X2) together had a positive and significant effect on work productivity $(\mathrm{Y})$. In the production process, productivity is supported by three main pillars, namely quantity (Quantity), quality (Quality), and safety (Safety). Productivity can only be achieved if the three elements of productivity above run in a balanced manner 
(Ramli, 2010:15). The implementation of Occupational Safety and Health programs and employee work productivity are important to be reviewed, because these two factors can affect company productivity in the aim of achieving the company's vision and mission. Considering that, every company needs to implement occupational health and safety that comprehensively strives to prevent accidents and diseases at work, so that it can reduce or eliminate accidents and occupational diseases and can increase the work productivity of employees within the company itself.

\section{CONCLUSION}

Partially and Simultaneously the Occupational Safety and Health program that has been implemented in the company has a very positive and significant effect on the employees work productivity of the Technical Section of PT. PLN (Persero) Masohi Branch, Central Maluku Regency. Occupational / work safety has a dominant effect on the employees work productivity of the Technical Section of PT. PLN (Persero) Masohi Branch, Central Maluku Regency.

\section{REFERENCES}

1. Anwar Prabu Mangkunegara. 2011. Manajemen Sumber Daya Manusia Perusahaan.

2. Moenir. 1983. Pendekatan Manusia and Organisasi Terhadap Pembinaan. Kepegawaian.

3. Afrida, BR. 2003. Ekonomi Sumber Daya Manusia. Jakarta. Ghalia Indonesia.

4. Barnes, D. F. 2019. Electric power for rural growth: how electricity affects rural life in developing countries. Routledge.

5. Benach, J. et al, 2014. Precarious employment: understanding an emerging social determinant of health. Annual review of public health, 35.

6. Dessler, Gary. 1997. Management Sumber Daya Manusia.Terjemahan. Benyamin. Molan.Edisi Bahasa Indonesia. PT Prenhallind. Jakarta

7. Ghozali, Imam. 2013. Aplikasi Analisis Multivariat dengan Program IBM SPSS.Edisi 7.

8. Lacal-Arántegui, R. 2019. Globalization in the wind energy industry: contribution and economic impact of European companies. Renewable energy, 134, 612-628.

9. Lestari, T., \& Trisyulianti, E. 2009. Hubungan Keselamatan and Kesehatan (K3) dengan Produktivitas Kerja Karyawan. Jurnal.Institut Pertanian Bogor.

10. Malik, A. 2019. Creating Competitive Advantage through Source Basic Capital Strategic Humanity in the Industrial Age 4.0. International Research Journal of Advanced Engineering and Science, 4(1), 209-215.

11. Milyandra, 2009. http://mily.wordpress.com/. Diakses pada 2 Juni 2014.

12. Nurjaman, Kadar. 2014. Manajemen Personalia. Bandung: CV Pustaka Setia.

13. O'brien, J. 2019. Category management in purchasing: a strategic approach to maximize business profitability. Kogan Page Publishers.

14. Palmer-Wilson, K. et al, 2019. Impact of land requirements on electricity system decarbonisation pathways. Energy policy, 129, 193-205.

15. Ramli S. 2010. Sistem Manajemen Keselamatan and Kesehatan Kerja.Jakarta: Dian.

16. Skład, A. 2019. Assessing the impact of processes on the Occupational Safety and Health Management System's effectiveness using the fuzzy cognitive maps approach. Safety science, $117,71-80$.

17. Sugiyono. 2005. Metode Penelitian Kuantitatif Kualitatif and R\&D. Bandung: Alfabeta.

18. Suma'mur.P.K. 1986. Keselamatan Kerja and Pencegahan Kecelakaan. PT. Gunung.

19. Wilson, M. G. et al, 2004. Work characteristics and employee health and well-being: Test of a model of healthy work organization. Journal of occupational and organizational psychology, 77(4), 565-588.

20. Zanchi, L., Zamagni, A., Maltese, S., Riccomagno, R., \& Delogu, M. (2020). Social Assessment in the Design Phase of Automotive Component Using the Product Social Impact Assessment Method. In Perspectives on Social LCA (pp. 105-117). Springer, Cham. 